\title{
Academic aspirations of undergraduate students of Punjab Agricultural University, Ludhiana
}

\author{
Anjana Rai and Kanwaljit Kaur
}

Received: 03.07.2018; Revised: 20.10.2018; Accepted: 02.11.2018

See end of the paper for authors' affiliations

\section{Anjana Rai}

Department of Extension

Education and Communication

Management, College of Home

Science, Punjab Agricultural

University, Ludhiana (Punjab)

India

Email : anjanarai192@

gmail.com
ABSTRACT : The present study was conducted to know and compare the factors affecting academic aspirations of undergraduate students of Punjab Agricultural University, Ludhiana.A sample of 150 students was selected through purposive sampling technique from three colleges of Punjab Agricultural University, Ludhiana having Government funded programmes namely B.Sc. (Hons.) Home Science, B.Sc. (Hons.)Agriculture, B.Tech. (Agricultural Engineering and Technology). Fifty five percentage of students aspired for further study followed by service in Government and private sector. Only six per cent of the students were aspired to become entrepreneur. Significant variations were found among students of different colleges in relation to aspirations for job in Government sector. There was no association of the level of academic performance, father's occupation and mother's occupation with aspirations of the students, but significant association was observed between aspirations of the students and independent variables like father's education, mother's education, counseling services and family background.

KEY WORDS: Academic performance, Aspirations, Entrepreneur

- HOW TO CITE THIS PAPER : Rai, Anjana and Kaur, Kanwaljit (2018). Academic aspirations of undergraduate students of Punjab Agricultural University, Ludhiana. Asian J. Home Sci., 13 (2) : 545-549, DOI: 10.15740/HAS/AJHS/13.2/545-549. Copyright@ 2018: Hind Agri-Horticultural Society. 